\title{
The Relationship Between Educational Games and the Development of Motor, Language, and Social Skills in Children Ages 3-4 Years
}

\section{Santy Siregar ${ }^{1}$, Herbert Wau², and Sri Hartini3}

${ }^{1}$ University of Prima Indonesia,Public Health Faculty,Jl. Sekip, Simp. Sikambing, Medan, 20113, Indonesia

2,1 University of Prima Indonesia, Public Health Faculty, Jl. Sekip, Simp. Sikambing, Medan, 20113, Indonesia

${ }^{3}$ University of Prima Indonesia,Psychology Faculty, Jl. Sekip, Simp. Sikambing, Medan, 20113, Indonesia

\section{Abstract}

As educational tools, games do not effectively stimulate the development of motor, language, and social in children of kindergartens and early childhood programs. This study aims to determine the relationship between educational games and the

Corresponding Author:

Santy Siregar

santy siregar76@yahoo.com

Herbert Wau

bert_fetp@yahoo.com

Sri Hartini

psikologi@unprimdn.ac.id

Received: 21 January 2018

Accepted: 8 April 2018

Published: 17 May 2018

Publishing services provided by

Knowledge $\mathrm{E}$

(c) Santy Siregar et al. This article is distributed under the terms of the

Attribution License, which

permits unrestricted use and redistribution provided that the original author and source are credited.

Selection and Peer-review under the responsibility of the 2nd International Meeting of Public Health 2016 Conference Committee.

\section{S OPEN ACCESS} development of motor, language, and social skills in early childhood and kindergarten at district of Medan Selayang. Data was obtained from a questionnaire and through observations of the behavior of children when interacting using the educational games at school (100 children), which was measured by using questionnaires as well as the Denver Developmental Screening Test (DDST) for motor skills, the Vineland Social Maturity Scale (VSMS) for social skills, and the Verbal Language Development Scale (VLDS) for language skills. Univariate and bivariate analysis methods were used to analyze the observational data. The chi-squared test was used to analyze the relationship between educational games and the development of motor, language, and social. This Research shows that $70 \%$ of games used as educational games are ineffective, but the majority of children (63\%) are able to use educational games well due to their familiarity with this tool. The results show that development of language is still lacking in many of the children (41\%). A statistically significant relationship was found between educational games and the development of motor skills ( $p$ value $0.028<0.05$ ) and development of social skills ( $p$ value $0.014<0.05$ ). No statistically significant difference was found between educational games and the development of language skills ( $p$ value $0.858>0.05$ ). It is recommended that schools provide an effective educational games that stimulates the development of motor, language, and social and maximizes the role of the teacher.

Keywords: Games Educational Tool, development of motor, social, and language skills 


\section{INTRODUCTION}

Every child that reaches the peak of lived experience will generate brain activity that stimulates the growth of new synapses and dendrites, and will ultimately improve the quality of the brain. When providing play opportunities for children in early childhood and in kindergarten, it is necessary to classify the type and form of the game to ensure that it is appropriate with age [7]. When selecting the best games to support early childhood education, kindergartens and early childhood programs, must pay attention to the educational elements contained in the games. If the type of game that is selected does not correspond to the child's age, he/she will have difficulty achieving optimal development of motor, language, and social [2]. Based on the data obtained from the survey, there are 100 kindergartens and early childhood education programs at Medan. There are 21 early childhood education programs and 7 kindergartens at Medan Selayang. From the results of the short interviews at 10 teachers in early childhood teachers and kindergarten, 7 teachers assessed the lack of available tools in their school's educational games and this resulted in a lack of stimulation; this can inhibit the children's growth and development, which can make it difficult for them to interact with others. If children brain is never stimulated, the brain tissue will shrink there by decreasing optimal functioning of that organ. This has led to stunted development of motor, language, and social in children. Teachers have learned the importance of using educational games to support normal development of these skills in children. They pay attention to the use fulness of the games and the need to select ones that are age-appropriate. Educational games can development motor in children as they engage in activities using the tools in the games. This stimulates children's minds and supports their emotional and social development, improving their creativity as well as their cognitive, sensory, and motor development [6]. This study aims to determine the relationship between the Games Educational and the development of motor, language, and social skills in children aged 3-4 years.

\section{METHODS}

This study used a quantitative and a cross-sectional exploratory qualitative mixedmethod approach. The study population was students in 21 early childhood programs and 7 kindergartens at District Medan Selayang, Indonesia. The sample included 100 students and 29 teachers. Data from the interviews with teachers were analyzed qualitatively, while data from the interviews with students were analyzed quantitatively. 
The following instruments were used to collect the data: a questionnaire, a check list sheet, the Denver Developmental Screening Test (DDST), the Vineland Social Maturity Scale (VSMS), and the Verbal Language Development Scale (VLDS). The chi-squared test was used to analyze the quantitative data. Multivariate analysis was conducted using MANOVA.

\section{RESEARCH RESULTS AND DISCUSSIONS}

\subsection{Overview of the Respondents}

A general overview of the respondents in this study is presented in Table 1.

TABLE 1: Overview of the Study Respondents.

\begin{tabular}{|c|c|c|}
\hline Sex & Number & Percentage(\%) \\
\hline Male & 55 & 55 \\
\hline Female & 45 & 45 \\
\hline Total & 100 & 100 \\
\hline $\begin{array}{l}\text { Development } \\
\text { of Motor }\end{array}$ & Number & Percentage(\%) \\
\hline Normal & 74 & 74 \\
\hline Disorder & 26 & 26 \\
\hline Total & 100 & 100 \\
\hline $\begin{array}{l}\text { Development } \\
\text { of Language }\end{array}$ & Number & Percentage(\%) \\
\hline Normal & 59 & 59 \\
\hline Disorder & 41 & 41 \\
\hline Total & 100 & 100 \\
\hline $\begin{array}{c}\text { Development } \\
\text { of Social }\end{array}$ & Number & Percentage (\%) \\
\hline Normal & 60 & 60 \\
\hline Disorder & 40 & 40 \\
\hline Total & 100 & 100 \\
\hline
\end{tabular}

From Table 1, $55 \%$ of the respondents were male and $45 \%$ of the respondents were female. Moreover $74 \%$ of the children had normal development of motor skill and $26 \%$ had disorder development of motor skill; $59 \%$ of the children had normal development of language skills and $41 \%$ had deficient development of language skills; $60 \%$ of the children had normal development of social skills and $40 \%$ had deficient development of social skills. 


\subsection{The relationship between the Educational games and the development of Motor, Language, and Social Skills in Children Aged 3-4 Years}

To determine the relationship between the Educational Games and development the motor, language, and social in children aged $3-4$, this study used a cross-sectional research design and evaluated the results using a chi-squared test. The results are presented in Table 2.

TABLE 2: Relationship between the Educational Games and Development of Motor, Language, and Social in Children Aged 3-4 Years.

\begin{tabular}{|c|c|c|c|c|}
\hline \multirow{2}{*}{$\begin{array}{l}\text { Educational } \\
\text { Games }\end{array}$} & \multicolumn{2}{|c|}{ Development of Motor } & \multirow[t]{2}{*}{ Count } & \multirow[t]{2}{*}{ p value } \\
\hline & Normal & Disorder & & \\
\hline Complete & 47 & 16 & 63 & 0.858 \\
\hline Not complete & 27 & 10 & 37 & \\
\hline \multirow{2}{*}{$\begin{array}{l}\text { Educational } \\
\text { Games }\end{array}$} & \multicolumn{2}{|c|}{ Development of Language } & Count & p value \\
\hline & Normal & Disorder & & \\
\hline Complete & 43 & 20 & 63 & 0.028 \\
\hline Not complete & 16 & 21 & 37 & \\
\hline \multirow{2}{*}{$\begin{array}{l}\text { Educational } \\
\text { Games }\end{array}$} & \multicolumn{2}{|c|}{ Development of Social } & Count & p value \\
\hline & Normal & Disorder & & \\
\hline Complete & 43 & 20 & 63 & 0.014 \\
\hline Not complete & 17 & 20 & 37 & \\
\hline
\end{tabular}

Based on Table 2, there is a significant relationship between educational games and the development language skill ( $p$ value $=0.028$; $p$ value $<0.05$ ), as well as between educational games and the development social skills ( $p$ value $=0.014 ; p$ value $<0.05$ ). There is no significant relationship between educational games and the development of motoric skills of children ( $p$ value $=0.858$; $p$ value $>0.05$ )

Table 3 shows that the development of language proficiency ( $p$ value $=0.014$ ) and social skills ( $p$ value $=0.028$ ) had a very strong relationship with the educational games. From the results, shows that R-Squared for Language Proficiency test are 51 $\%$, it means there are relationship between educational games and the development of language. 
TABLE 3: The Relationship Between Educational Games and the Development of Motoric, Social and Language skills in Children Ages 3-4 Years Old.

\begin{tabular}{l|c|c|c|c|c|}
\hline Source & $\begin{array}{c}\text { Dependent } \\
\text { Variable }\end{array}$ & $\begin{array}{c}\text { Type III Sum of } \\
\text { Squares df }\end{array}$ & $\begin{array}{c}\text { Mean } \\
\text { Square }\end{array}$ & F test & Significant \\
$\begin{array}{l}\text { Corrected } \\
\text { Model }\end{array}$ & $\begin{array}{c}\text { The } \\
\text { development } \\
\text { of Motoric }\end{array}$ & $.006^{a}$ & .006 & .032 & .859 \\
$\begin{array}{c}\text { The } \\
\text { development } \\
\text { of Language } \\
\begin{array}{c}\text { The } \\
\text { development } \\
\text { of Social }\end{array}\end{array}$ & $1.458^{b}$ & 1.458 & 6.286 & .014 \\
\hline $\begin{array}{l}\text { R Squared }=, 000 \text { (Adjusted R Squared }=-.010)_{a} \\
\text { R Squared }=, 060 \text { (Adjusted R Squared }=.051)_{b}\end{array}$ & 1.160 & 4.977 & .028 \\
R Squared $=, 048$ (Adjusted R Squared $=.039)_{c}$ & & \\
\hline
\end{tabular}

\subsection{The Relationship Between Educational Games and Motor Capabilities in Children}

Based on these results, there is no correlation between educational games and the development motor skill ( $p$ value $=0.858>0.05$ ). The results of this study are not consistent with the results of research by Waldi, who found that manipulating play dough had a positive effect on children's motor abilities. There is a disconnect between educational games and the development motor skills of children in because the majority of the respondents (74 percent) already had normal development motor skills by this age. This is reinforced by the results of the interview with the respondents' teacher (Teacher \#1): "Actually, our kids already have fine motor skills because most of our games besides the classroom tool require strength and shrewdness from our students. In their home environments, they've been tought to perform tasks according to their age. "The development motoric skill of children is determined by factors other than educational games alone. Fine development motor skills continue to grow better every day. When they are 3-4 years old, development motor skills start getting better, allowing them to coordinate the skills of their fingers with their senses. This influences the skills of a child in using his or her fingers, especially the thumb and forefinger, which is manifested in basic writing beginning in early childhood [11]. Fine motor movements are involved when kindergarten-age children, and even younger children, begin to brush their teeth, comb their hair, put on their shoes, and etc [12]. 


\subsection{The Relationship Between Games as Educational Tools With Children's Language Abilities}

Based on the results of the research, there is a relationship between educational games and the development language skill ( $p$ value $=0.028<0.05$ ). The results are consistent with the results of research by Sain, who found that educational game had an influence on development language skill. Educational game can in fact stimulate the development language. This is consistent with the results of interviews conducted with Teacher \#2: "The developments of motor our students are good, but still lack of languages developments. How can we go forward if educational games mostly outside and play alone? we see that children no longer want to play with their friends because they become used to playing games alone on the phone at home". Parents and teachers need to know the specific types of games that are appropriate so that they can prepare good educational games [4]. This shows the importance of knowledge of educational games so that one can choose the type of game according to the age of the child, and ensure that the child's development of gross motor, fine motor, language and socialization skills as well as independence can be optimized. Language development in children includes describing images in their own words, understanding two commands given together [10]. Example "Take this over to the table and give it to the teacher", expressing a simple desire "I would like a drink", recounting events experienced in a simple manner and imitating noises from surrounding sources.

\subsection{Educational Games and Their Relationship with Social Skills in Children}

Based on the results, there is a relationship between educational games and the development social skill ( $p$ value $=0.014<0.05$ ). The results are consistent with the results of research by Sain, who found that there are relationship between educational games and the development social skills of children. This is consistent with the results of interviews conducted with Teacher \#3: "I think that kids today are lazy to playing together with friends, because they have more fun when playing with their parents. Moreover, when they back to home they must to study with parents.

One of the factors that affects the activity levels of children is finding the kinds of games that fit their needs. A matching game will help the child to get know the norms and rules of society, as well as develop social relationships with others. The child should feel confident that he had a friend to play together. When children play alone, they lose the opportunity to learn from their friends. Conversely, if too much 
time is spent playing with other children, it can result in children having insufficient opportunities to entertain themselves and find their identities. Social skills which children must learn include the ability to work in groups, being patient and waiting their turn, expressing regret when they make a mistake, reacting to something considered untrue and demonstrating respect for others [8].

\subsection{Multivariate Analysis of the Relationship Games Educational Tool with the Development of Motor Skills, Social Skills and Language in Children Ages 3-4 Years Old}

Based on results from the Multivariate Analysis of Variance (MANOVA test), it can be seen that the development language $(p$ value $=0.014$ ) and social skills ( $p$ value $=0.028$ ) had a significant relationship with the educational games. From the results obtained via the R Squared Language Proficiency test, educational game contribute $51 \%$ to develop language skill. Environmental factors influence the development of language and social skills, for example, the provision of educational games and the socialization of children [1]. Educational games may be able to quickly stimulate the motor development of children, but to stimulate the children's social and language skills requires a special version of educational games and assistance from their parents [9]. Child development is an important concern for both parents and teachers because it will shape the children's lives even when they become adults. If parents do not pay attention to the development of their children, providing little guidance and intervention, the children will lack of development [3]. Educational games are fun and can improve language skills, critical thinking skills and associating with the environment. They can also strengthen and enhance personal development, foster a closer relationship between educators and learners, channel the energies of the students, etc [5]. Education should enhance various aspects of childhood development such as motor skills, language abilities, social skills and general intelligence.

\section{CONCLUSIONS}

There is a significant relationship between educational games and the development language skill ( $p$ value $=0.028<0.05$ ), as well as between educational games and the development social skills ( $p$ value $=0.014<0.05$ ). There is no significant relationship between educational games and development motoric skills ( $p$ value $=0.858>0.05$ ). 


\section{References}

[1] Andriana, Dian. 2011. Tumbuh Kembang dan Terapi Bermain pada Anak. Jakarta: Salemba Medika.2011

[2] Herlina T., Subagyo, \& Agustin R., 2010. Perbedaan Perkembangan Anak Usia 45 Tahun Antara yang Ikut PAUD dan Tidak Ikut PAUD, Jurnal Penelition Kesehaton Forikes. 1(4): 249-258. (18 Juli 2011) static schoolrack.com. 2010

[3] Hidayat, A.A, (2008), Pengantor Ilmu Keperawaton Anak 1,Salemba Medika, Jakarta.2008

[4] Mulyati, Yeti. (2010). Artikel Penggunaan Alat Permainan Edukatif: Upaya Membantu Perkembangan Bahasa dan Kognitif Anak Usia 3-6 tahun, https://id.scribd.com/document/246375808/Artikel-Penggunaan-Alat-PermainanEdukatif-pdf (diakses tanggal 8 Oktober 2015)

[5] Prakoso. (2009). Stimulasi Anak Usia Dini (Panduan Praktis Bagi Ibu dan Calon Ibu). Bandung: Alfabeta, 2009

[6] Sain, Sry Nur Hasana; Amatus Yudi Ismatu; Abram Babakal (2013). Pengaruh Alat Permainan Edukatif terhadap Aspek Perkembangan pada Anak Prasekolah di wilayah Puskesmas Ondong Kabupaten Kepulauan Siau Tagulandang Biaro. Jurnal e-NERS (eNS), volume 1, nomor 1 Maret 2013, hal.16-20.2013

[7] Soetjiningsih (2013). Tumbuh Kembang Anak, Cetakan II, Buku Kedokteran EGC, Jakarta.2013

[8] Sujiono, (2010). Bermain Kreatif Berbasis Kecerdasan Jamak. Jakarta: Indeks.2010

[9] Suprianti, Y, (2004). Konsep Dasar Keperawatan Anak, Buku Kedokteran EGC, Jakarta.2004

[10] Susanto, Ahmad. 2011. Perkembangan anak usia dini. Jakarta: Kencana Prenada Media.2011

[11] Waldi, MaksumEka. (2014). Pengaruh Bermain Playdough Terhadap Kemampuan Motorik Halus Anak Di TK Pertiwi Talakbroto, Simo, Boyolali Tahun Pelajaran 2013/2014. http://eprints.ums.ac.id/29474/15/NASKAH_PUBLIKASI_ILMIAH.pdf. (diakses tanggal 10 September 2015)

[12] Yusuf, 2013, Perkembangan Motorik. hhtp://www.motorikanak.com (diakses tanggal 20 Januari 2014). 